\title{
RELATO DE CASO: DESLOCAMENTO DE ABOMASO À DIREITA E VÓLVULO ABOMASAL EM VACA HOLANDESA
}

\author{
(Case Report: left displacement of the abomasum and abomasal volvulus in a Holstein Cow)
}

Louise Krueger, Ivan Roque de Barros Filho

Universidade Federal do Paraná, Curitiba, Paraná, Brasil

*Correspondência: louisekrueger@hotmail.com

RESUMO: O deslocamento de abomaso (DA) pode ocorrer pelo posicionamento anormal do órgão na cavidade abdominal para o lado esquerdo ou direito (DAD), que pode evoluir para vólvulo abomasal (VA) (Niehaus, 2008). O relato é de uma vaca Holandesa, seis anos de idade, pesando $540 \mathrm{~kg}$, parida há quatro meses. Sua criação era a pasto, recebendo silagem e ração duas vezes ao dia após a ordenha. Há dois dias apresentava perda de apetite e queda na produção de leite. No momento do atendimento pelo médico veterinário o animal olhava seguidamente para o flanco e escoiceava o abdômen do lado direito. No exame físico o animal apresentou hipomotilidade ruminal, taquicardia (92 bpm), taquipneia $(33 \mathrm{mpm})$, temperatura retal de $38,1^{\circ} \mathrm{C}$, mucosas róseas claras, tempo de preenchimento capilar de dois segundos e desidratação de $6 \%$. Ao auscultar a área simultaneamente à percussão pode-se auscultar o "ping" metálico, que relacionando com os sinais clínicos suspeitou-se de DAD. Optou-se pela realização de laparotomia exploratória com acesso pela fossa paralombar direita. Após depilação e antissepsia, realizou-se anestesia local com cloridrato de lidocaína $(7 \mathrm{mg} / \mathrm{kg})$, seguido de incisão de pele e camadas musculares. Na cavidade abdominal notou-se o abomaso laterodorsalmente rente às últimas costelas e repleto de gás e líquido. Foi realizada abomasocentese para drenagem do gás e líquido serosanguinolento $(500 \mathrm{~mL})$ de coloração vermelha enegrecida e odor fétido utilizando uma agulha 45X1,5 acoplada a um equipo adaptado. Ao palpar o abomaso percebeu-se uma torção ventralmente, caracterizando VA, que foi desfeito manualmente. Realizou-se abomasopexia, fechou-se a cavidade abdominal e aplicou-se spray cicatrizante a base de quelato de cobre e zinco, mistura de propano/butano, EDTA dissódico de cobre e de zinco sobre a ferida cirúrgica. No pós-operatório imediato foram administrados três litros de soluções eletrolíticas compostas de cálcio, magnésio, cloreto de sódio, cloreto de postássio, lactato de sódio, acetilmetionina e sorbitol por via intravenosa visando promover a motilidade ruminal, hidratar e corrigir o possível déficit ácido-básico da paciente. Recomendou-se a administração de $30 \mathrm{~mL}$ de sulfadoxina, trimetoprim e piroxicam nos cinco dias subsequentes e cuidados com a ferida cirúrgica. Orientou-se o fornecimento de alimentos volumosos de boa qualidade, evitando ofertar concentrados nos próximos três dias. Após 30 dias a vaca estava recuperada e saudável. Vacas com até 2 semanas pós parto possuem um risco maior de desenvolver DA e VA (Niehaus, 2008), pois este período está associado com mudanças hormonais e estresse metabólico (Doll et al., 2009), mas neste caso o animal já havia parido há mais tempo. Os sinais clínicos descritos no relato, assim como os sons de "ping" auscultados, coincidem com os descritos por Niehaus (2008). Casos de VA apresentam sinais clínicos mais graves, pois o abomaso pode desvitalizar e necrosar, além de produzir um fluido tingido de sangue (Niehaus, 2008), como relatado no caso. O DAD e VA ocorrem em vacas leiteiras em nosso meio. O rápido diagnóstico e intervenção cirúrgica são essenciais para a recuperação do animal e podem ser feitos rapidamente a campo.

Palavras-chave: abomasocentese; bovino; cirurgia; DAD; laparotomia.

\section{Referências}

DOLL, K.; SICKINGER, M.; SEEGER, T. New aspects in the pathogenesis of abomasal displacement. The Veterinary Journal, v.181, p.90-96, 2009.

NIEHAUS, A. J. Surgery of the Abomasum. Veterinary Clinics of North America: Food Animal Practice, v.24, p.349-358, 2008. 

